\title{
構造物に作用する地震荷重への氷盤の影響 ICE EFFECT ON FOUNDATION LOAD OF OFFSHORE STRUCTURE DURING EARTHQUAKES
}

\author{
山内 豊 ${ }^{1}$ ・亀崎一彦 ${ }^{2}$ \\ Yutaka YAMAUCHI, Kazuhiko KAMESAKI \\ 1 工修 NKK エンジニアリング研究所（テ514-0393 三重県津市雲出鋼管町 1 番地） \\ 2 正会員 工博同上
}

This paper describes effects of surrounding ice sheets on foundation design of gravity-based structures while an earthquake occurs. To simulate a situation that an offshore structure placed in moving or non-moving ice sheets encounters an earthquake, we performed vibration tests in the ice tank. We gave a sinusoidal vibration to a model foundation to represent an earthquake. The test showed that the load combination of moving ice and earthquake depends on the indentation velocity and an interaction between structure and non-moving ice may mitigate the seismic load.

Keywords : offshore structure, earthquake, ice, vibration test, foundation load, ice load

\section{1.はじめに}

地震を想定する必要がある氷海域に設置される海 洋構造物の設計においては, とりわけ水荷重と地震 力が重要な荷重となる。局部荷重としては氷盤との 接触部に作用する氷荷重が, また全体荷重は地震力 が支配的となろうが, サハリン沿岸のような海域で は, 氷荷重と地震力が同時に作用する可能性も考え られる，局部荷重や全体荷重及び構造応答には，地 震時の水盤と構造物の相互作用が影響する。三浦等 ${ }^{1), 2)}$ は定着水盤中の構造物の地震応答特性, 滑動安定 性に及ぼす水の影響を理論モデルによって調査して いる. 一方，移動水中で水荷重と地震力が同時に作 用する場合の複合荷重の特性は十分には解明されて

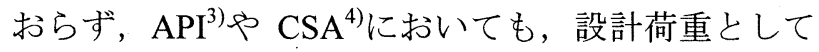
これらの複合荷重の考え方を明確にしていない。本 研究では地震時の水荷重の特性や, 構造基部荷重, 構造応答への水盤の影響を解明し, 水荷重と地震力 が重畳する場合の設計荷重について評価を行なうこ とを目的とする。著者等はその第一段階として，氷 海水槽において構造物模型の水中加振実験を実施し た. 構造物が移動水または定着水の中で地震に遭遇 する状況を再現し, 水荷重と地震力が重畳する場合 の構造物及び地盤への影響について調査した。本論 文ではその解析結果について報告し, 地震と氷を考 慮する必要がある海域に設置される構造物の設計荷 重について一考察を行った.

なお, 本研究は通産省からの委託事業として日本 海洋開発産業協会が平成 5 年度から 12 年度にかけて 実施した「海洋構造物に作用する氷荷重に関する研 究」の一環として実施したものである.

\section{2. 水中加振試験}

\section{（1）試験方法}

鉛直壁型重力式構造物を想定し, 縮尺 $1 / 50$ の $800 \mathrm{~mm}$ 幅四角柱鋼製模型を氷海水槽（長さ $20 \mathrm{~m}$, 幅 $6 \mathrm{~m}$, 水深 $1.8 \mathrm{~m}$ ）で振動させる試験を実施した。図-1 は模型の概観図で, 表-1 は模型の要目を想定実機と 比較して示したものである。局部水荷重を計測する ために, 模型の前面と水板との接触部は, 幅 $88 \mathrm{~mm}$, 高さ $120 \mathrm{~mm}$ の 9 枚の荷重計測パネルで分割した.ま た模型の後面は, 中央の $88 \mathrm{~mm}$ 幅パネルとその両側

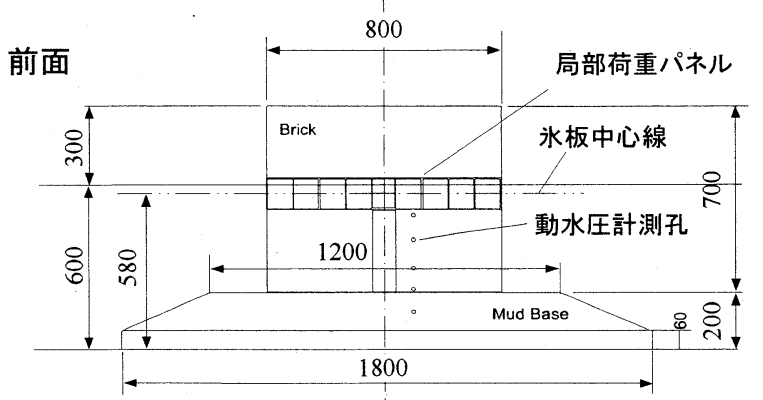

図-1 供試模型

表-1 模型寸法

\begin{tabular}{|l|c|c|}
\hline & 想定実機 & 供試模型 \\
\hline 縮尺 & $1 / 1$ & $1 / 50$ \\
\hline 水線幅 & $40 \mathrm{~m}$ & $80 \mathrm{~cm}$ \\
\hline 高さ & $45 \mathrm{~m}$ & $90 \mathrm{~cm}$ \\
\hline 没水部深さ & $30 \mathrm{~m}$ & $60 \mathrm{~cm}$ \\
\hline 全重量 & $200,600 \mathrm{ton}$ & $1.172 \mathrm{ton}$ \\
\hline 排水量 & $97,580 \mathrm{ton}$ & $0.75 \mathrm{ton}$ \\
\hline 重心高さ & $12.7 \mathrm{~m}$ & $29.2 \mathrm{~cm}$ \\
\hline
\end{tabular}


に 2 枚ずつの $177 \mathrm{~mm}$ 幅パネルによって 5 分割した.

図-2に試験装置を示す。構造物模型は，構造物底 部の水平剪断力を計測する全体荷重検力計と，地盤 挙動を模擬するためのバネを介して振動台に取り付 けられている。振動台は水海水槽の水中台車上にあ り，水中台車は曳引車に剛に連結されている。模型 の水深は $600 \mathrm{~mm}$ （実機 $30 \mathrm{~m}$ 相当）とし，加振時動水 圧への海底地盤の影響を考慮して仮床を水中台車に 取り付けた。振動台は水平 1 方向に振動し，振幅と 周波数を変えることができる.

水況としては移動水盤と定着水盤を想定した。移 動水に対応する実験では，模型を振動させながら， 水中台車を曳引車で牽引して水板中に貫入させた。

定着水盤に対応する実験では，水海水槽のほぼ中央 に水中台車を固定し，模型の周囲に氷板を密着させ た後，模型を振動させた。これう一連の試験におい て, 局部水荷重 $f_{l}$, 構造基部剪断力 $F_{g x}$ を前述の検力 装置で,また模型の変位 $d_{s r}$ と加速度 $a_{x}$ をそれぞれレ ーザー変位計と加速度計で計測した。図-3に計測の 座標系を示す。

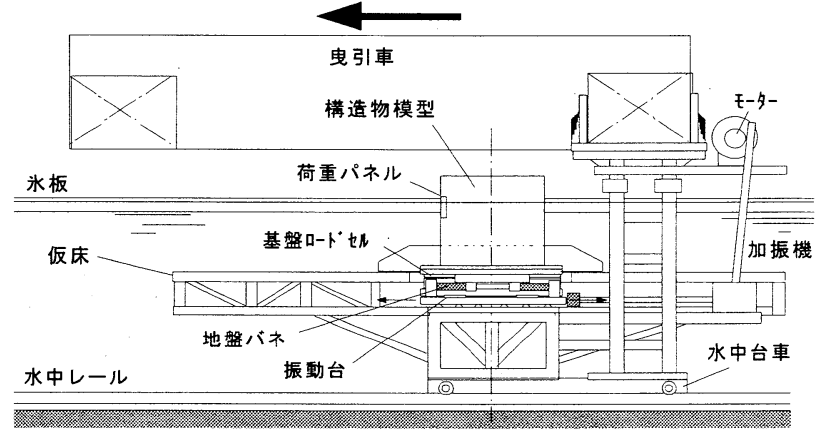

図-2 試験装置

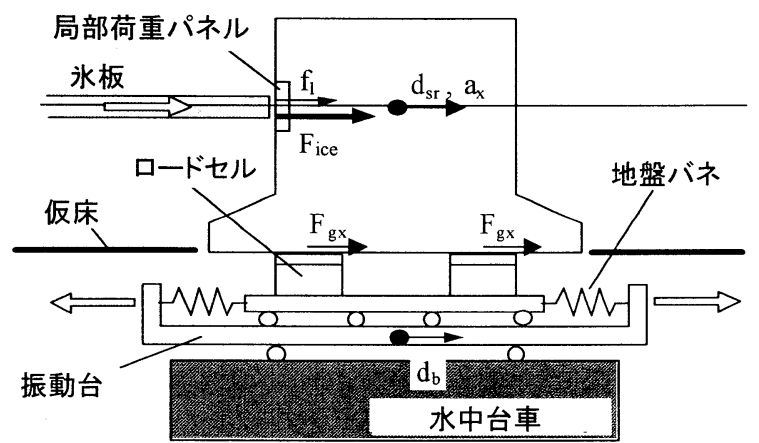

図-3 座標系

\section{(2) 試験条件}

実験に用いた模型水板の水厚は $40 \mathrm{~mm}$ ( $2 \mathrm{~m}$ 相当), 一軸圧縮強度は $80 \mathrm{kPa}$ (4MPa 相当) 及び $120 \mathrm{kPa}(6 \mathrm{MPa}$ 相当）とした。 なお圧縮強度は歪速度が $10^{-3} \mathrm{~s}^{-1}$ の時 の強度とした。サハリン島北東海域の平均水厚は 1 $\sim 1.3 \mathrm{~m}$, 平均圧縮強度は $1.5 \mathrm{Mpa}$ 程度と言われており, 試験条件はこの海域に対しては厳しい設定となって いる。模型底部と振動台との連結は剛連結と前述の バネ連結の 2 種類とし，それぞれ RIGID-model, MS-model と呼ぶことにする. MS-model の地盤バネ のバネ定数 $K_{s}$ は $\mathrm{N}$ 值 20 の砂地盤を想定して
$4.32 \mathrm{kN} / \mathrm{mm}$ （10.8MN/mm 相当）とした. 減衰比は約 0.06 であった。

サハリン海域の地震として遠山等 ${ }^{5)}$ は, 100 年再現 期間に対して $0.2 \mathrm{~g}, 1000$ 年再現期間に対して $0.5 \mathrm{~g}$ の ハザード曲線を提案している。しかしながら, 複合 荷重の特性を調べる上では，氷荷重と地震力の大き さに大差をつけない方が，氷板の影響をより理解し やすいと考え, 試験では加速度振幅 $a_{v}$ が約 $0.1 \mathrm{~g}$ とな るように加振した。 $0.1 \mathrm{~g}$ の振動は前記ハザード曲線 では 50 年の再現期間に相当する。加速度波形は $\sin$ 波とし，周波数 $f_{v}$ は $1 \sim 7 \mathrm{~Hz}(0.1 \sim 1 \mathrm{~Hz}$ 相当）の範囲 で変化させた。表-2に規則地震波の特性を示す。

移動水盤に対応する加振貫入試験では，貫入速度 $V$ をサハリン海域の平均的な水盤移動速度（0.3〜 $0.5 \mathrm{~m} / \mathrm{s})$ を参考にして $30 \mathrm{~mm} / \mathrm{s}$ と $100 \mathrm{~mm} / \mathrm{s}(0.21 \mathrm{~m} / \mathrm{s}$, $0.71 \mathrm{~m} / \mathrm{s}$ 相当）の 2 種類之し, 地船特性，氷の強度， 地震波を変えて合計 48 ケースの試験を行った。また， 定着水盤に対応する加振実験では地盤特性, 地震波 を変化させて合計 12 ケースの試験を行った。表-3 にそれぞれの試験条件を示した。

表-2 規則地震波

\begin{tabular}{|c|c|c|c|}
\hline & $\begin{array}{c}\text { 周波数 } \\
\mathrm{fv}(\mathrm{Hz})\end{array}$ & $\begin{array}{c}\text { 加速度振幅 } \\
\mathrm{av}(\mathrm{g})\end{array}$ & $\begin{array}{c}\text { 変位振幅 } \\
\mathrm{dv}(\mathrm{mm})\end{array}$ \\
\hline \hline RW1 & 1.0 & 0.06 & 15.0 \\
\hline RW2 & 1.5 & 0.10 & 11.0 \\
\hline RW3 & 2.0 & 0.10 & 6.0 \\
\hline RW4 & 2.5 & 0.10 & 4.0 \\
\hline RW5 & 5.0 & 0.10 & 1.0 \\
\hline RW6 & 7.0 & 0.20 & 1.0 \\
\hline
\end{tabular}

表-3 試験条件

\begin{tabular}{|c|c|c|c|c|c|c|}
\hline 模型 & Test No. & $\begin{array}{l}\text { 貫入速度 } \\
\mathrm{V}(\mathrm{mm} / \mathrm{s})\end{array}$ & $\begin{array}{c}\text { 水厚 } \\
\mathrm{h}(\mathrm{mm}) \\
\end{array}$ & $\begin{array}{r}\text { 圧縮強度 } \\
\sigma \mathrm{c}(\mathrm{kPa})\end{array}$ & $\begin{array}{c}\text { 加振 } \\
\text { 周波数 } \\
\mathrm{fv}(\mathrm{Hz}) \\
\end{array}$ & $\begin{array}{c}\text { 加振 } \\
\text { 加速度 } \\
\text { av (g) } \\
\end{array}$ \\
\hline \multicolumn{7}{|c|}{ 氷板貫入をともなう振動試験（加振貫入試験） } \\
\hline \multirow{4}{*}{$\begin{array}{l}\text { MS-model } \\
\mathrm{Ks}= \\
4.32 \mathrm{kN} / \mathrm{mm}\end{array}$} & $7-12$ & 30 & 40 & \begin{tabular}{|l|}
111 \\
\end{tabular} & $1-7$ & $0.06-0.22$ \\
\hline & $18,20,24-27$ & 100 & 41 & $117-120$ & $1-7$ & $0.06-0.22$ \\
\hline & $32-37$ & 30 & 41 & \begin{tabular}{|l|}
78 \\
\end{tabular} & $1-7$ & $0.06-0.22$ \\
\hline & $46,47,51-54$ & 100 & $40-41$ & $77-79$ & $1-7$ & $0.06-0.21$ \\
\hline \multirow{4}{*}{$\begin{array}{c}\text { RIGID - } \\
\text { model }\end{array}$} & $1-6$ & 30 & 39 & 122 & $1-7$ & $0.06-0.23$ \\
\hline & $12-14,19-21$ & 100 & $40-41$ & $110-114$ & $1-7$ & $0.06-0.23$ \\
\hline & $24-29$ & 30 & 43 & 90 & $1-7$ & $0.06-0.23$ \\
\hline & $37,38,52-55$ & 100 & $39-41$ & $84-87$ & $1-7$ & $0.06-0.23$ \\
\hline \multicolumn{7}{|c|}{ 台車固定の振動試験 (固定水中加振試験) } \\
\hline $\begin{array}{l}\text { MS-model } \\
\mathrm{Ks}= \\
4.32 \mathrm{kN} / \mathrm{mm}\end{array}$ & f 4 - f 9 & 0 & 42 & $123-126$ & $1-7$ & $0.06-0.20$ \\
\hline $\begin{array}{l}\text { RIGID- } \\
\text { model }\end{array}$ & $\mathrm{f} 13-\mathrm{f} 18$ & 0 & 42 & $125-128$ & $1-7$ & $0.06-0.20$ \\
\hline
\end{tabular}

\section{（3）加振貫入試験の結果}

模型の定常的な貫入と振動の双方によって氷板は 模型の近傍でフレーキングを伴う圧壊によって破壊 した. 図-4 は MS-model の全体水荷重 $F_{i c e}$ (局部水荷 重 $f_{l}$ の総和), 構造基部剪断力 $F_{g x}$, 構造変位 $d_{s r}$ の代 表的な時系列を振動台の変位 $d_{b}$ とともに示したもの で，貫入速度による明らかな差が認められる。以下 に主に氷板強度が $120 \mathrm{kPa}$ のケースの解析結果につ いて述べる。

\section{a) 構造応答}

図-5 に構造物の振動変位 $d_{s r}$ の周波数特性を振動 


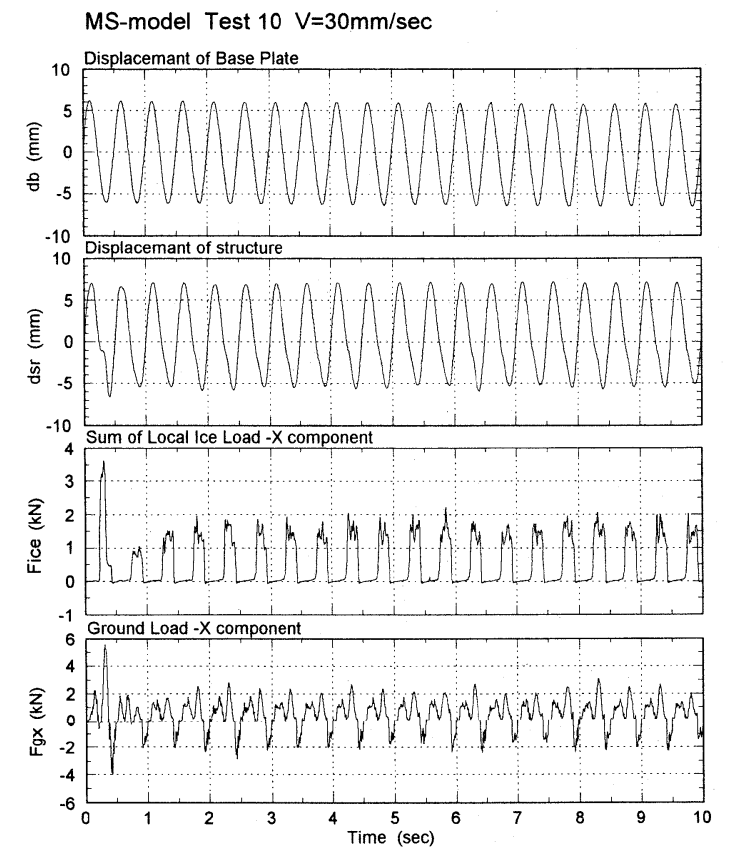

図-4 加振貫入試験の変位・荷重の時系列

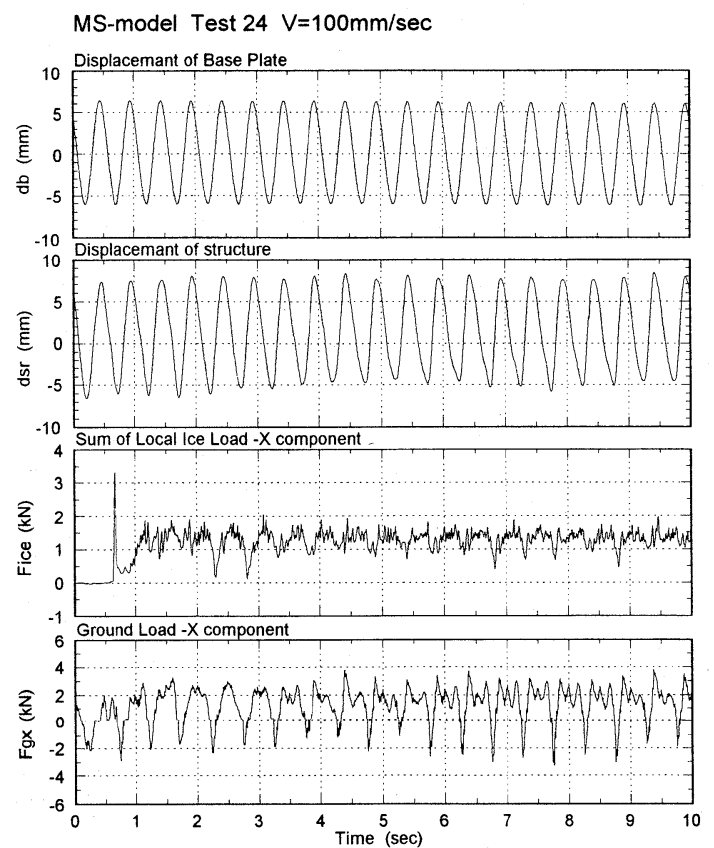

(MS-model, $\mathrm{h}=40 \mathrm{~mm}, \sigma_{\mathrm{c}}=120 \mathrm{kPa}$ )
台の加振変位 $d_{b}$ に対して示した。模型そのものは十 分に剛であり, この応答特性は地盤バネによるもの である. 今回の模型では加振周波数が $5 \mathrm{~Hz}$ の時に同 調する傾向が見られた。この同調周波数には重要な 意味はないが，移動水盤中ではこの同調時の構造応 答が平水中に比べ緩和されているのがわかる.

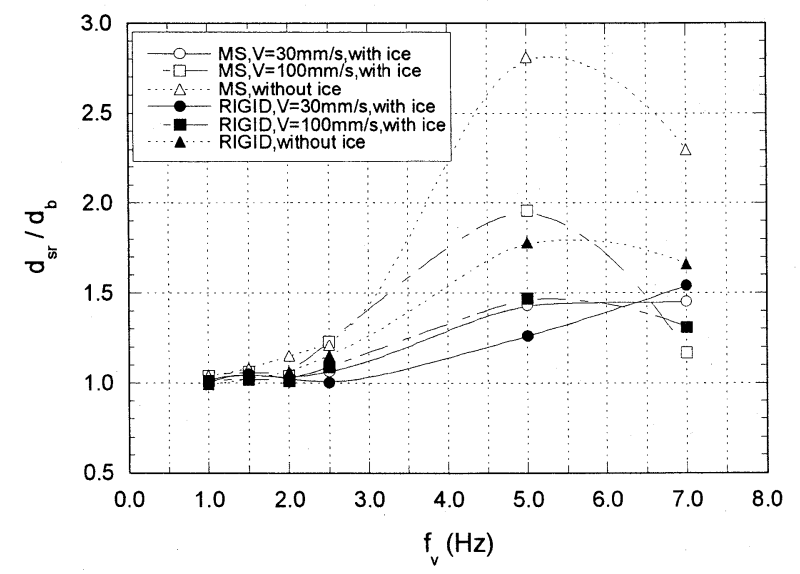

図-5 加振貫入試験時の構造応答 $\left(\sigma_{c}=120 \mathrm{kPa}\right)$

\section{b）水荷重と地震力}

全体水荷重の時系列の波形は主に貫入速度によっ て図-6に示すような 3 種類のパターンに分類できた. 図-4に示した例は図-6 の Case-A と Case-C に相当す る。氷板との接触と離脱が交互に繰り返される Case-A の波形は貫入速度が $30 \mathrm{~mm} / \mathrm{s}$ の場合に多く見 られた. Case-C は不規則な変動を繰り返す波形で模 型は常に氷板と接触している状態にある。このケー スは貫入速度が速い $100 \mathrm{~mm} / \mathrm{s}$ のケースで見られた。 Case-B は Case-A から Case-C への遷移的な状態で, 断続的な波形ではあるが荷重が 0 になることはない. 地震力はここでは構造物の挙動に伴う慣性力と定
義する. 平水中加振試験の結果から推定した付加質 量 $m$ と, 氷中加振時の模型の平均加速度振幅 $a_{x m}$ か ら, 氷中加振時の地震力 $F_{e}$ は(1)式によって解析的に 求めた。

$$
F_{e}=(M+m) \times a_{x m}, M \text { は模型質量 }
$$

図-7 に氷荷重 $F_{i c e}$ と地震力 $F_{e}$ の比を示した. 今回の 試験条件では, 氷荷重と地震力の比は $\sigma_{\mathrm{c}}=120 \mathrm{kPa}$, $a_{v}=0.1 \mathrm{~g}$ の領域で約 0.7 であった。 これらの比は貫入 速度の影響をほとんど受けない。なお，この領域で の $F_{e}$ は約 $3 \mathrm{kN}$ である.

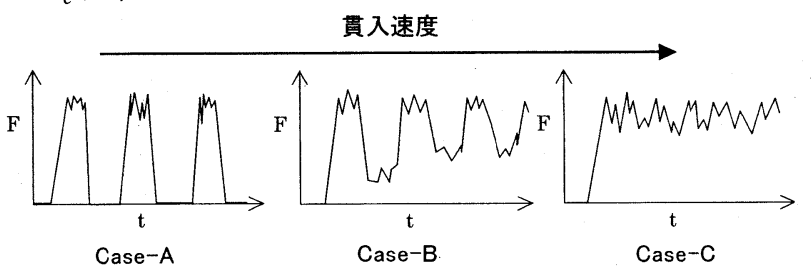

図-6 水荷重の時系列パターン

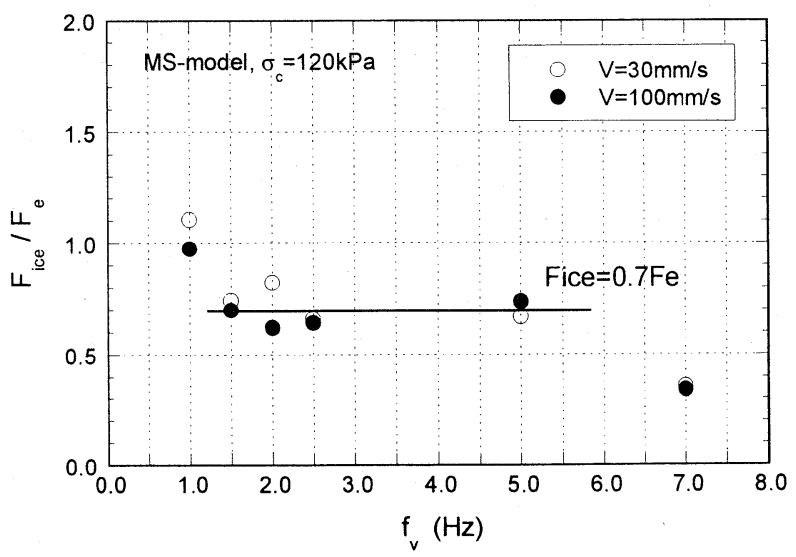

図-7 水荷重と地震力の比 (MS-model, $\sigma_{\mathrm{c}}=120 \mathrm{kPa}$ ) 


\section{c）構造基部剪断力}

構造基部には振動にともなう地震力と氷板接触部 からの氷荷重が重畳して作用寸る. 図-4 の $F_{g x}$ の時 系列を見ると，貫入速度によって波形だけでなく大 きさも異なる. 図-8 に $\sigma_{\mathrm{c}}=120 \mathrm{kPa}$ の場合の, 氷中加 振時の基部剪断力と平水中加振時の基部剪断力の比 $F_{g x} / F_{g x 0}$ を加振周波数に対して示した. $F_{g x 0}$ は平水中 加振時の地震力に相当する. 貫入速度が $30 \mathrm{~mm} / \mathrm{s}$ の場 合, 基部剪断力の大きさは平水中加振時の荷重と概 水同じ值を示し，氷板の影響はほとんど現われない。 一方, 貫入速度が $100 \mathrm{~mm} / \mathrm{s}$ の場合には, 振動周波数 が $5 \mathrm{~Hz}$ 以トの時に基部㷙断力に明らかな水板ひ影響 が見られ， $F_{g x 0}$ の 10〜80\%増の值を示した。 図-7で 氷荷重と地震力の絶対值の割合は貫入速度の影響を ほとんど受けていないことから， $F_{g x} / F_{g x 0}$ の貫入速度 による差は変動する荷重の位相によるものと考えら れる. 貫入速度にともなう位相の影響については後 述する.

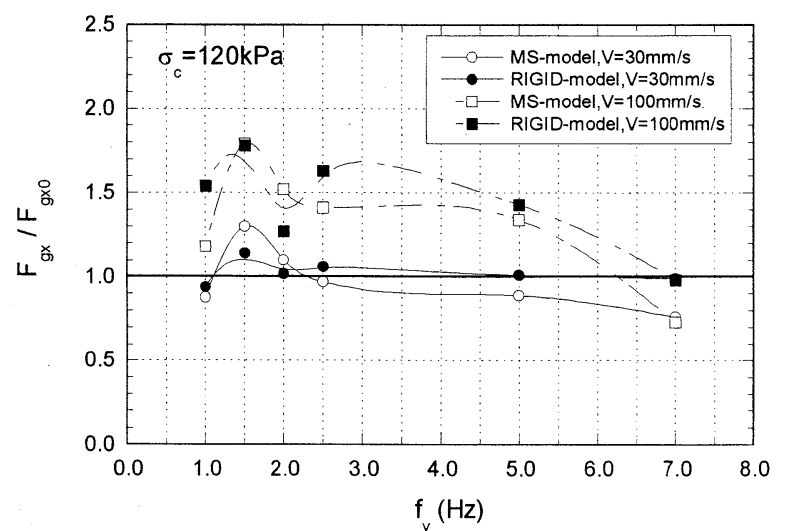

図-8 水板貫入時と平水中の加振時構造基部剪断力の比 $\left(\sigma_{c}=120 \mathrm{kPa}\right)$

\section{d）局部永荷重}

図-9 は MS-model で貫入速度が $30 \mathrm{~mm} / \mathrm{s}$ の場合の 有効水圧力 $P_{i c e}$ と局部水圧力 $P_{l}$ をそれぞれ氷の一軸 圧縮強度 $\sigma_{\mathrm{c}}$ で無次元化し, 加振周波数との関係を示 したものである．局部水圧力はそれぞれの荷重計測 パネルで計測された局部荷重 $f_{l}$ をパネル内の氷との 接触面積で除したものであり, 有効水圧力は全体水 荷重 $F_{i c e}$ を水厚 $h$ 及び構造幅 $B$ で除した見掛けの水 圧力である. 同じ図には, 加振せずに氷板に貫入し た場合の氷圧力も示した。

局部水圧力は加振周波数によっても異なり， $\sigma_{\mathrm{c}}$ の $0.6 \sim 1.3$ の範囲に分布した. 有効水圧力は局部水圧 力の $60 \sim 70 \%$ の值を示しており，これは構造物の全 幅に亘って同時に氷板が破壊していないことによる. 振動周波数が $2 \mathrm{~Hz}$ よりも小さい領域では局部荷重は 加振しない時の氷荷重よりも大きくなる傾向が見ら れた。一方，振動周波数が $2 \mathrm{~Hz}$ よりも大きい領域で は局部荷重は加振しない時の荷重とほぼ同じと見な せた。 また貫入速度が $100 \mathrm{~mm} / \mathrm{s}$ の場合にも同じよう ような特性が得られ, 承荷重への貫入速度の影響は 小さいと考えられた.

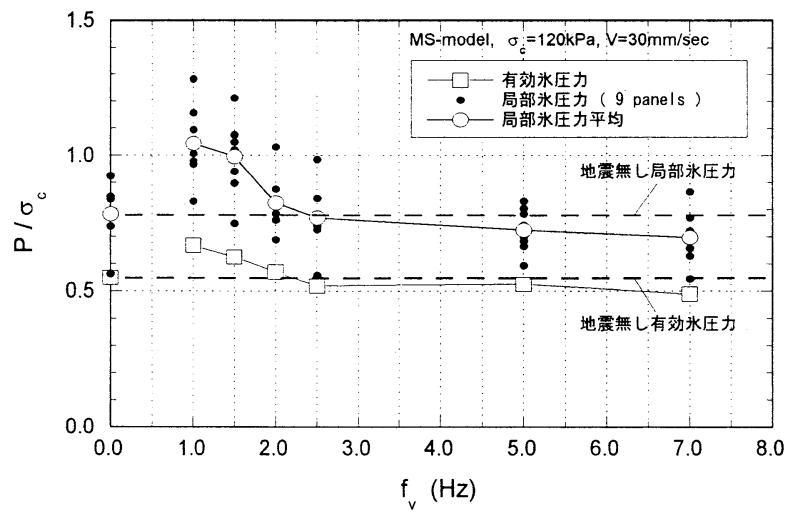

図-9 局部水圧力への地震の影響 (MS-model, $\left.\sigma_{\mathrm{c}}=120 \mathrm{kPa}\right)$

\section{（4）固定水中の加振試験}

固定水中の試験では模型の振動による氷板への周 期的な載荷で，承板は模型の近傍で破壊した。しか しながら氷板の弾性と地盤バネにより氷板は一度に 破壊せず，模型の前後振動にともなって徐々に破壊 し，最終的に模型と氷板の隙間が振動変位にほぼ一 致すると水板破壊が終了する．その後は振動にとも なって模型と水板の隙間から水が噴き出寸現象が観 察された。

\section{a）氷板による地震力の緩和}

図-10 に典型的な水荷重 $F_{i c e}$ と構造基部剪断力 $F_{g x}$ の時系列を示した。初期の氷板破壊の間は, 氷板か ら受ける反力と慣性力の方向が相反するため, 基部 剪断力は緩和される傾向にある. 水板の破壊ととも に剪断力は徐々に大きくなり, 氷板の破壊が終わる と基部剪断力は定常的な波形を示寸. 図-11 に模型 が振動を始めてから基部剪断力が定常状態になるま での振動の波数 $\left(T_{i} \cdot f_{v}, T_{i}\right.$; 定常状態に至るまでの時 間）と振動周波数の関係を示寸. 加振周波数が $2 \mathrm{~Hz}$ よりも小さい場合には基部剪断力の緩和は顕著に現 れず，最初の数波で氷板破壊が終わる．今回の実験 は加振加速度をほぼ一定にしているため周波数の小 さいケースでは加振振幅が大きく, 従って一波当た りの水板の歪が大きく模型の全幅に亘って局部的な 破壊が促進したと考えられる。一方周波数が $2 \mathrm{~Hz}$ よ りも大きいケースでは定常状態に至るまでに 10 波 以上の振動を要している。この場合には氷板の歪が 小さく, また氷板強度の不均一性も手伝って局部的

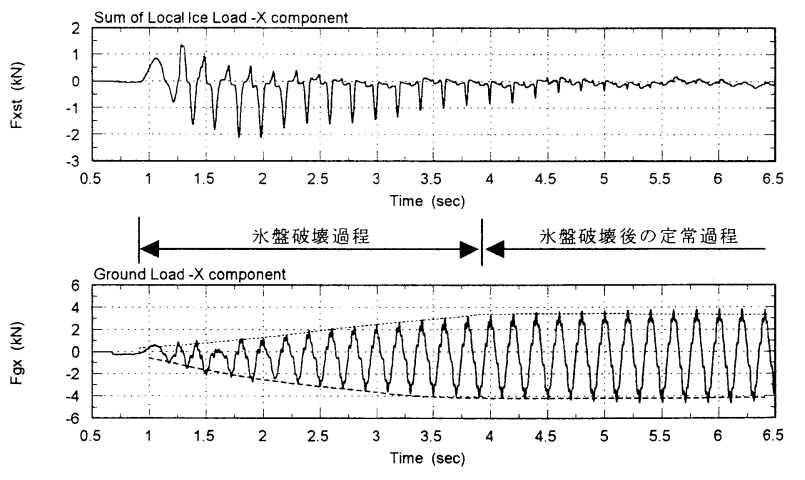

図-10 氷荷重と基部剪断力の時系列（MS-model, Test f 2) 
な破壊が場所を変えながら発生することにより，全 幅に亘る破壊に時間を要すると考えられる。実際に 観測される地震波では，大きな振動が今回の試験の ように定常的に継続することはなく，地震発生後 10 秒程度で減衰することが多い，そのことを考慮すれ ば定着水はその反力と破壊に要するエネルギ一吸収 で地震力を緩和すると考えられる。

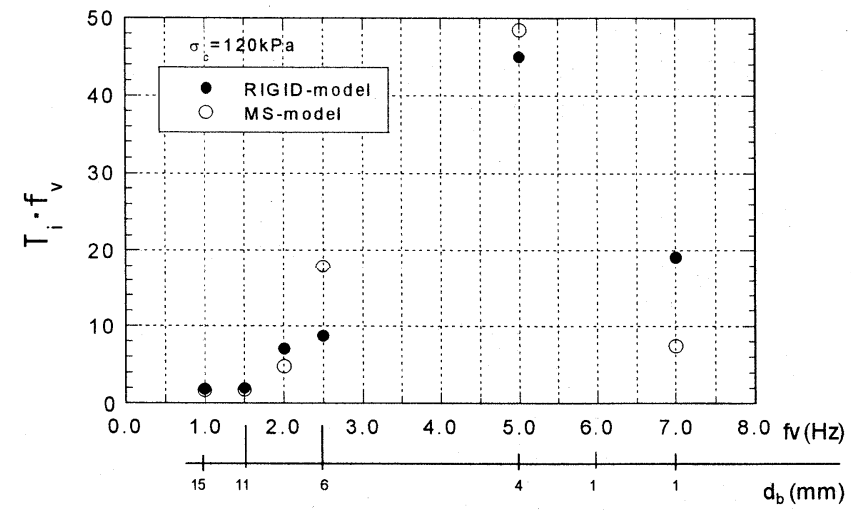

図-11 定常振動に至るまでの振動波数（ $\left.\sigma_{c}=120 \mathrm{kPa}\right)$

\section{b）永板破壊後の基盤荷重と構造応答}

図-12 に氷板が破壊した後の定常的な構造基部剪 断力と平水中加振時の剪断力の比 $F_{g x} / F_{g x 0}$ を示す. 水 板破壊後の基部剪断力は平水中加振時の 100 150\% の值を示した. 氷板の破壊長は数 $\mathrm{mm} \sim 20 \mathrm{~mm}$ と比較 的狭く，動水圧の上昇によるものと考えられる.

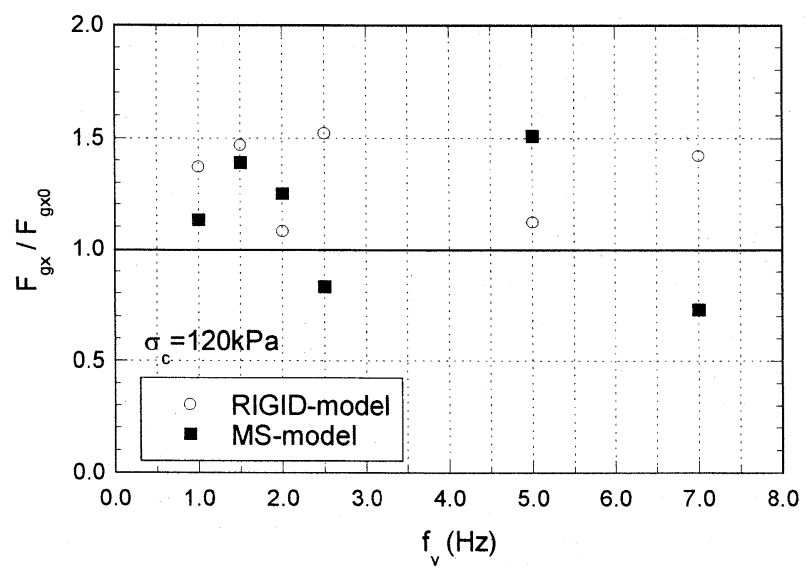

図-12 固定水中と平水中の基部剪断力の比 $\left(\sigma_{\mathrm{c}}=120 \mathrm{kPa}\right)$

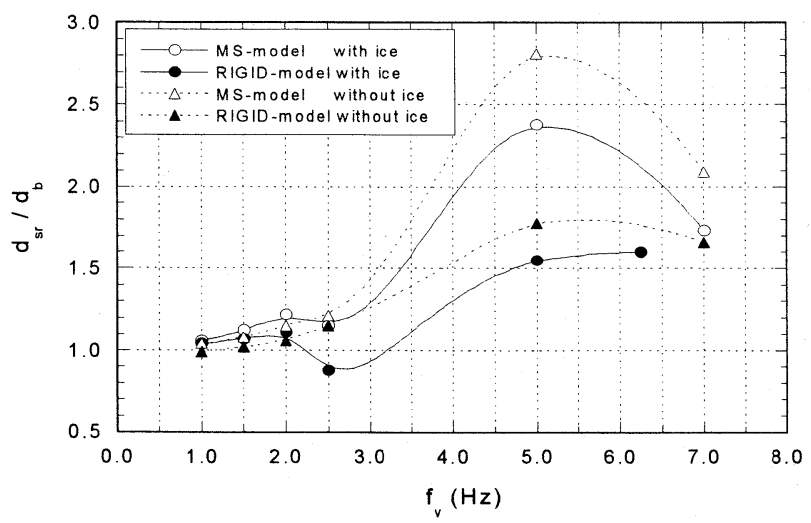

図-13 固定水中加振試験時の構造応答（定常過程）
図-13 は定常的な状態における構造応答 $d_{s r} / d_{b}$ を示 す. 貫入時と同じく，水板の存在で構造応答が減衰 しているが，図-5 の貫入時の結果に比べ減衰の割合 は小さい，貫入時には常に氷板が構造物に押し寄せ るのに対し，固定水中の試験では図-10に示したよ うに定常状態における水板の反力が著しく小さくな るためと推察される。

\section{3. 複合荷重への貫入速度の影響}

移動水盤の中で構造物に地震が作用する場合に， 構造物は極めて危険な荷重条件に曝される，特に滑 動や地盤挙動にともなう構造物の倒壊を考える時, 構造基部に作用する氷荷重と地震力の重畳は重要な 問題である。しかしながら，今回の一連の試験によ って重畳の度合いには水盤の移動速度が大きく影響 すると考えられた。以下に氷荷重と地震力の位相に 及ぼす移動速度の影響について考察した。

図-14 は地震力に対する水荷重の位相遅れ時間 $\tau$ の加振周期 $T_{v}$ に対する割合を示したものである。水 板の移動速度（構造物の貫入速度）が $30 \mathrm{~mm} / \mathrm{s}$ の遅い 場合には両荷重の間には周期の 30〜 60\%の位相差が あり，特に構造物が水板の方向に運動する時には逆 位相に近くなって慣性力の影響が緩和される。構造 基部剪断力は，単純に氷荷重と地震力の絶対值の和 にならず，大きい方の荷重が支配的となる。図-7に 示したように，今回の試験では地震力が氷荷重より も大きいので，基部剪断力は地震力に概ね等しくな る。一方氷盤の移動速度が $100 \mathrm{~mm} / \mathrm{s}$ の速い場合には 慣性力の位相と氷荷重の位相にほとんど差が見られ ず，慣性力に氷荷重の 50〜80\%が付加され，構造基 部剪断力が平水中に比べて増加することになる。図
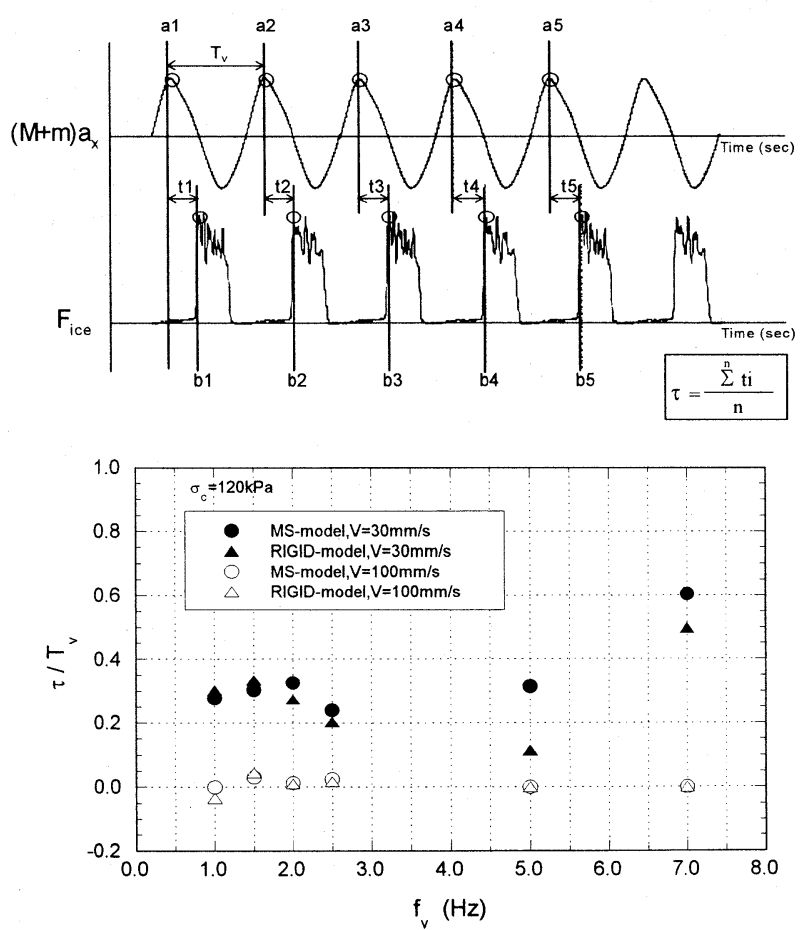

図-14 加振貫入試験の地震力（慣性力）に対する氷荷重 の位相遅れ 
-15 は以上の移動速度の影響を示したものである. 今回の試験では構造物の平均的な加振速度は約 $60 \mathrm{~mm} / \mathrm{s}$ であり, 水板の移動速度が構造物の加振速度 よりも速くなると，氷板は構造物の振動にかかわら ず構造物と接触し氷荷重が常に作用すると考えられ る.
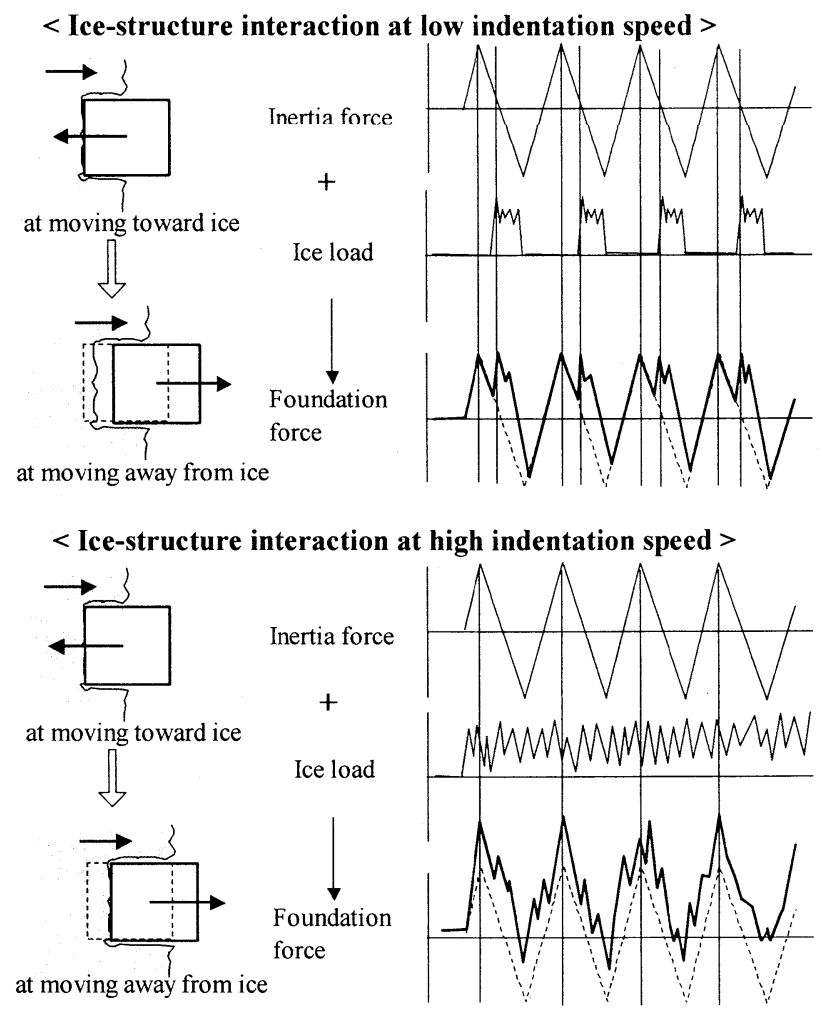

図-15 水荷重と地震力の複合荷重への貫入速度の影響

\section{4. 設計荷重に関する考察}

氷荷重と地震力が同時に作用することは希である と考えられるが，設計条件としては海水，地震それ ぞれの出現確率を検討した上で, 設計にとって適切 な同時発生の組合わせを考える必要がある。一方で 移動水と地震が同時に発生する場合に, それらの相 互作用による局部荷重や構造基部に作用する全体荷 重の特性の調査が進めば，より合理的な設計荷重を 設定することができる.

今回の一連の試験によって, 地震時の構造基部剪 断力は，単純に氷荷重と慣性力の和では表されず， 氷盤の移動速度や振動周波数の影響を受け, 特に氷 盤速度の影響が大きいことが明らかになった。

構造物が設置される氷海域における地震と移動水盤 の同時発生条件の下で，今回調查したような地震力 と水荷重の非線形的な複合荷重の特性を考慮すれば, 構造基部に作用する全体荷重をより適切に評価する ことができると考えられる.さらに，サハリン海域 のように比較的穏やかな水況を考えるとき, 設計条 件として再現期間が 200 年や 1000 年の地震と同時発
現する可能性のある氷盤の厚さは $1 \mathrm{~m}$ に満たないか もしれない。そのような条件では，もともと氷荷重 は地震力に比べてはるかに小さく，承盤の影響は極 めて小さいと考えられる.

構造物局部の設計に重要となる局部水荷重に関し ては，今回の試験結果では構造物の振動の影響は小 さく，これまでの移動水盤に対する局部荷重と同じ 評価法を用いることができると考えられた。

定着水中の構造物については振動によって氷盤と の接触部から移動水盤と同じ程度の氷荷重を受ける ことになり，局部構造の設計への考慮が必要である. 一方, この場合の構造基部に対しては氷盤は地震時 の慣性力を緩和寸る方向に作用すると考えられた.

\section{5. まとめ}

海水の作用を受ける構造物に，地震が同時に発生 する場合の構造物の挙動や全体荷重の特性を実験的 に調查した。一連の試験によって地震・海水同時作 用時の構造基部に作用する全体荷重には氷盤の移動 速度が大きく影響することが明らかになり，また慣 性力に加えて氷荷重の影響が顕著に現れる遷移速度 は地震動の速度にほぼ等しくなると推察された。著 者らは，今回の試験で得られた知見を基に，地震と 海水の同時作用時の荷重及び構造応答を推定するこ とのできる理論モデルを開発している．規則地震波 の試験結果を基にモデルの検証を行い，観測地震波 等によって実機ベースのシミュレーションを実施し ている，海氷と地震の同時発生条件も考慮に入れた 上で，局部荷重や構造基部に作用する全体荷重の考 え方について，さらに調査を進める予定である.

\section{参考文献}

1) 三浦房紀，野沢逸男，榊 信昭，平野勝志: 水海 構造物の地震時挙動と滑動安定性に及ぼす水の影 響, 土木学会論文集, 第 409 号 /VI-11, pp.65-73, 1989.

2) 三浦房紀，玉 均: 水との相互作用を考慮に入れ た氷海構造物の地震応答特性に及ぼす水の影響, 土木学会論文集, 第 483 号 / I-26, pp.117-125, 1994.

3) American Petroleum Institute (API) : Recommended practice for planning, designing, and constructing structures and pipelines for Arctic conditions, API recommended practice $2 N$ second edition, 1995.

4) Canadian Standards Association (CSA): General requirements, design criteria, the environment, and loads, CAN/CSA-S471-92, 1992.

5) Toyama, Y., Kato, K., Kamesaki, K., Yamauchi, Y. and Kurokawa, A.: Ice and earthquake loads on a structure in offshore Sakhalin, Proc POAC'01, Ottawa, Vol 2, pp.597-606, 2001. 